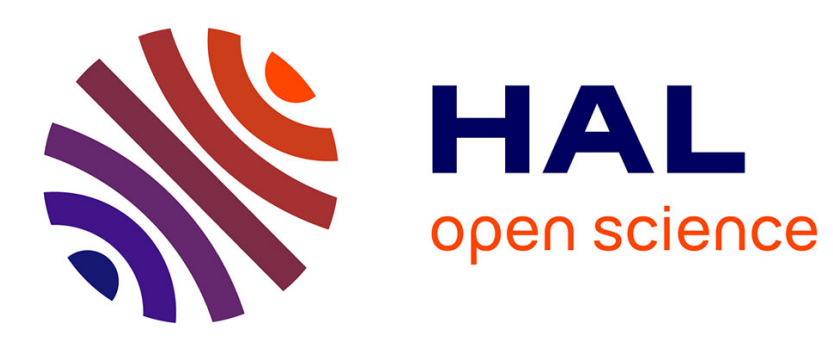

\title{
Effect of potassium on the tolerance to PEG-induced water stress of two white clover varieties (Trifolium repens L.).
}

Christophe Robin, Lisa Shamsung Noor, Armand Guckert

\section{To cite this version:}

Christophe Robin, Lisa Shamsung Noor, Armand Guckert. Effect of potassium on the tolerance to PEG-induced water stress of two white clover varieties (Trifolium repens L.).. Plant and Soil, 1989, 120, pp.153-158. 10.1007/BF02377063 . hal-02726224

\section{HAL Id: hal-02726224 \\ https://hal.inrae.fr/hal-02726224}

Submitted on 2 Jun 2020

HAL is a multi-disciplinary open access archive for the deposit and dissemination of scientific research documents, whether they are published or not. The documents may come from teaching and research institutions in France or abroad, or from public or private research centers.
L'archive ouverte pluridisciplinaire HAL, est destinée au dépôt et à la diffusion de documents scientifiques de niveau recherche, publiés ou non, émanant des établissements d'enseignement et de recherche français ou étrangers, des laboratoires publics ou privés. 


\title{
Effect of potassium on the tolerance to PEG-induced water stress of two white clover varieties (Trifolium repens $\mathrm{L}$. )
}

\author{
C. ROBIN, L. SHAMSUN-NOOR and A. GUCKERT \\ Laboratoire de Phytotechnie-I.N.R.A., E.N.S.A.I.A. 2, avenue de la Forêt de Haye, F-54500 Vandoeuvre \\ Les Nancy, France
}

Received 28 November 1988. Revised May 1989

Key words: nitrogen fixation, nodules, stomatal resistance, water potential

\begin{abstract}
The response to water stress was studied on white clover grown hydroponically. Two varieties (Crau and Huia) were both subjected to a moderate and a more-severe stress, induced by polyethylene glycol (10 and $20 \%$ respectively), in the presence of a nutrient solution poor in potassium $\left(\mathrm{K}_{1}=0.005 \mathrm{mM}\right)$, or abundantly supplied $\left(\mathrm{K}_{2}=5 \mathrm{mM}\right)$. Dawn water potential and nitrogen fixation (acetylene reduction activity) decreased with the increasing stress. Conversely, the stomatal resistance increased when osmoticum was added. Crau had a lower stomatal resistance to the deficit, than did Huia. In relation with the $\mathrm{K}$ supply, treatment $\mathrm{K}_{2}$ confirmed the superiority of Crau. Crau also showed greater nodule mass and number than Huia. The data show relationships between dawn water potential, stomatal resistance and nitrogen fixation activity.
\end{abstract}

\section{Introduction}

Water stress in plants influences many metabolic processes, and the extent of its effects depends on drought severity (Hsiao, 1973; Turner, 1986). Drought stress also results in a decrease in nitrogen uptake. For numerous legumes, nitrogen fixation has been shown to be sensitive to a reduction in the soil water. Drought could directly inhibit nitrogen fixation, which has been found more sensitive than photosynthesis (Sprent, 1972), although this loss of activity could be due also to an inhibition of the photosynthesis (Huang et al., 1975a). In temperate regions, legumes such as white clover are often subjected to drought. Moreover, the root nodules are mostly confined to the upper 50 to $150 \mathrm{~mm}$ of soil which often dries out during spells of drought. The inhibition of symbiotic nitrogen fixation due to water stress has been studied especially in Rhizobium-nodulated plants (Sprent, 1976) and in actinorhizal-nodulated tree (Sundström and Huss-
Danell, 1987). It has been well-established that potassium plays an important role in many physiological processes associated directly with nitrogen fixation and photosynthesis (People and Koch, 1979). However, little information is available about drought tolerance in conjunction with $\mathrm{K}$-fertilization in white clover (Guckert and Laperriere, 1987).

In this work we studied under artificial conditions, the time-course of the inhibition of nitrogenase activity by water stress in white clover. The two factors considered were potassium fertilization and clover variety. Crau (Ladino) and Huia (Hollandicum) are two varieties that have been previously studied (Shamsun-noor et al., 1989) for their tolerance to water deficit.

The effect of water stress was assessed here by measuring the leaf water potential and the stomatal resistance. The number, water content and mass of the nodules during the stress experiment were also determined. 


\section{Materials and methods}

\section{Plant material and growth conditions}

Seeds of two white clover varieties (Trifolium repens L.) cv Crau (Ladino) and cv Huia (Hollandicum) were incubated for $48 \mathrm{~h}$, on a filter paper and sterile vermiculite, to allow their germination. The unifoliated clover seedlings were transferred to a hydroponic system and inoculated with Rhizobium trifolii U.S.D.A. 2063. When the seedlings reached the 3-leaf stage, 120 plants were transplanted to a $45 \mathrm{~L}$. PVC box containing $20 \mathrm{~L}$ of a Wood-Cooper-Holding (WCH) nutrient solution (Wood et al., 1983). The nodules in the upper part of the roots remained just above the solution, which ensured their sufficient humidification. Two rates of potassium were applied: $0.005\left(\mathrm{~K}_{1}\right)$ and $5 \mathrm{mM} \mathrm{KCl}\left(\mathrm{K}_{2}\right)$. Plants were maintained in growth chambers under day/night temperatures of $23 /$ $18^{\circ} \mathrm{C}$, and relative humidity of $75 \%$ under a light intensity of about $300 \mu \mathrm{mol} . \mathrm{m}^{-2} . \mathrm{s}^{-1}$ on the canopy delivered during $14 \mathrm{~h}$ of daylight using $20 \mathrm{HQI}$ $400 \mathrm{~W}$ mercury vapor lamps.

\section{Water stress induction}

A polyethylene glycol solution (purified $\mathrm{PEG}$ 6000 (no 600) Merck, molecular weight 50007000 ) in WCH was used as osmoticum to induce moderate $(10 \%$ PEG $\mathrm{w} / \mathrm{v})$ or severe stress $(20 \%$ PEG w/v). The osmotic pressure of the control solution and each PEG solution was determined by a Beckman cryoscope. Two-months-old plants of each variety were selected according to their size. Water stress was then induced by dipping their root systems in the appropriate PEG solutions. Predrawn leaf water potential $(\Psi)$ was then determined at the end of the dark period, first, after 22 hours of the PEG treatment and subsequently daily. Measurements were made with a Schölander-type pressure bomb (Schölander et al., 1965).

The stomatal resistance was measured at the middle of the photoperiod on fully-expanded leaves of control and stressed plants (0 and 20\% PEG; $10 \%$ not determined), using a van Bavel diffusion porometer (van Bavel et al., 1965).

Plant dry matter, nodule number and nodule water content were measured and expressed as a percentage of the control.
The nitrogenase activity of the plants was estimated with the ARA method (Balandreau and Dommergues, 1973) as previously described (Shamsun-noor et al., 1989). The ethylene concentration was measured by gas chromatography using a steel column with $10 \% \quad \mathrm{Na}_{3} \mathrm{PO}_{4}$ on Spherosil XOB 075 . The nitrogenase activity was expressed as nmoles $\mathrm{C}_{2} \mathrm{H}_{4} \cdot \mathrm{g}^{-1}$ nodule fresh weight per hour of incubation.

\section{Statistical analysis}

Data were analyzed using the analysis of variance procedure. Means were classified (statitcf program) according to the Newman-Keuls test $(p=0.05)$.

\section{Results}

\section{Pre-dawn leaf water potential}

The leaf-water potential was measured every two days during the first five days of the treatment (Fig. 1). The potential of stressed plants decreased with the time and the decrease was larger between day 1

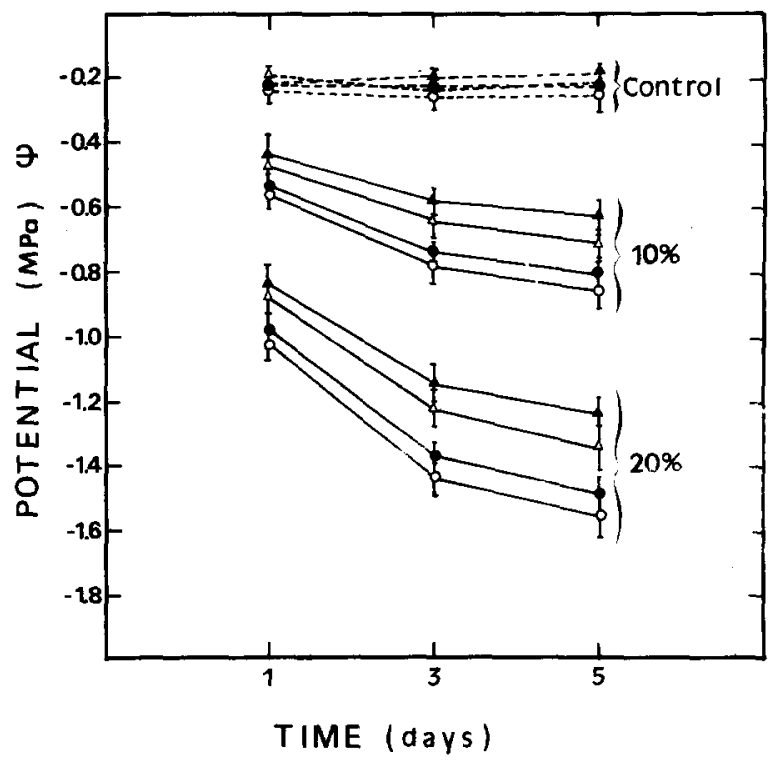

Fig. 1. Dawn water potentials (bars) of the 2 varieties of white clover (Crau and Huia) during the osmotic stress induced by PEG $(0,10$ and $20 \%)$ under 2 levels of $\mathrm{K}: \mathrm{K}_{1}=0.005$ and $\mathrm{K}_{2}=5 \mathrm{~m} M$. $\Delta$ Crau $\mathrm{K}_{2}, \Delta$ Crau $\mathrm{K}_{1}$; Huia $\mathrm{K}_{2}$; ○ Huia $\mathrm{K}_{1}$. 
and day 3 than between day 3 and day 5. Differences between the PEG treatments were large and obviously statistically significant.

The Crau variety maintained a significantly higher dawn water potential than the Huia variety, and a $\mathrm{K}$ effect with variety factor was clear.

\section{Stomatal resistance}

Figure 2 gives the stomatal resistance of some of the plants which remained constant for the control plants. However, PEG induced an increased in stomatal resistance and a significant difference was observed between the two cultivars subjected to a severe stress (20\% PEG). However, no significant "variety-PEG-Potassium" interaction was detected in general, but Crau seemed to have the best resistance, as shown by the significant "PEG-K" interaction at the end of the experiment.

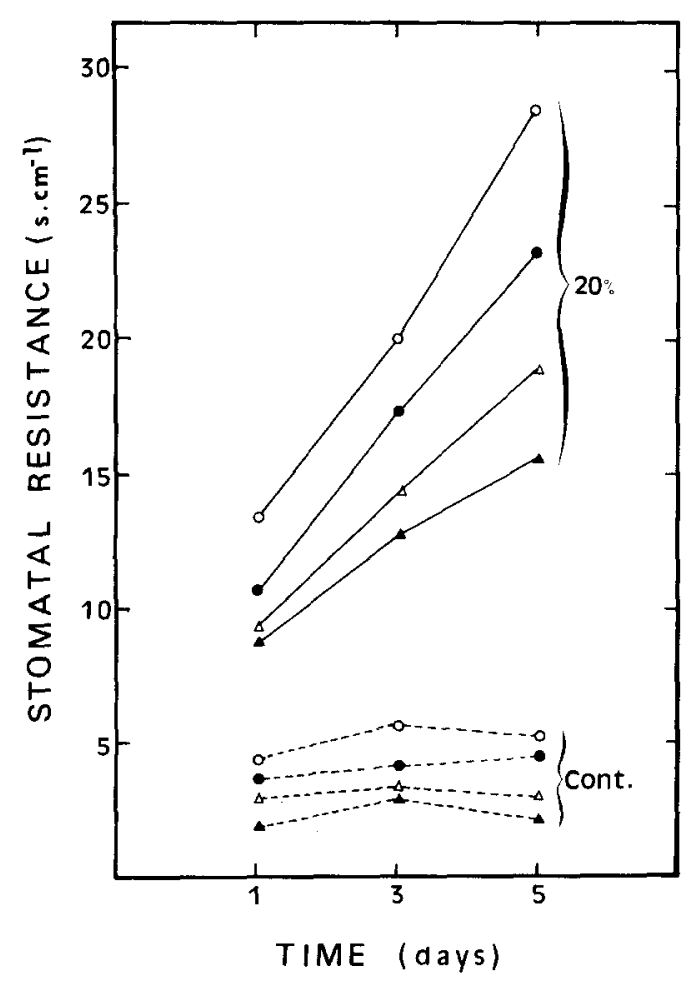

Fig. 2. Stomatal resistance of the 2 varieties during the osmotic stress induced by PEG $(0$ and $20 \%)$ under 2 levels of $\mathrm{K}$ : $\mathrm{K}_{1}=0.005$ and $\mathrm{K}_{2}=5 \mathrm{mM} . \Delta$ Crau $\mathrm{K}_{2}, \Delta$ Crau $\mathrm{K}_{1}$; $\bullet$ Huia $\mathrm{K}_{2} ;$ O Huia $\mathrm{K}_{1}$.

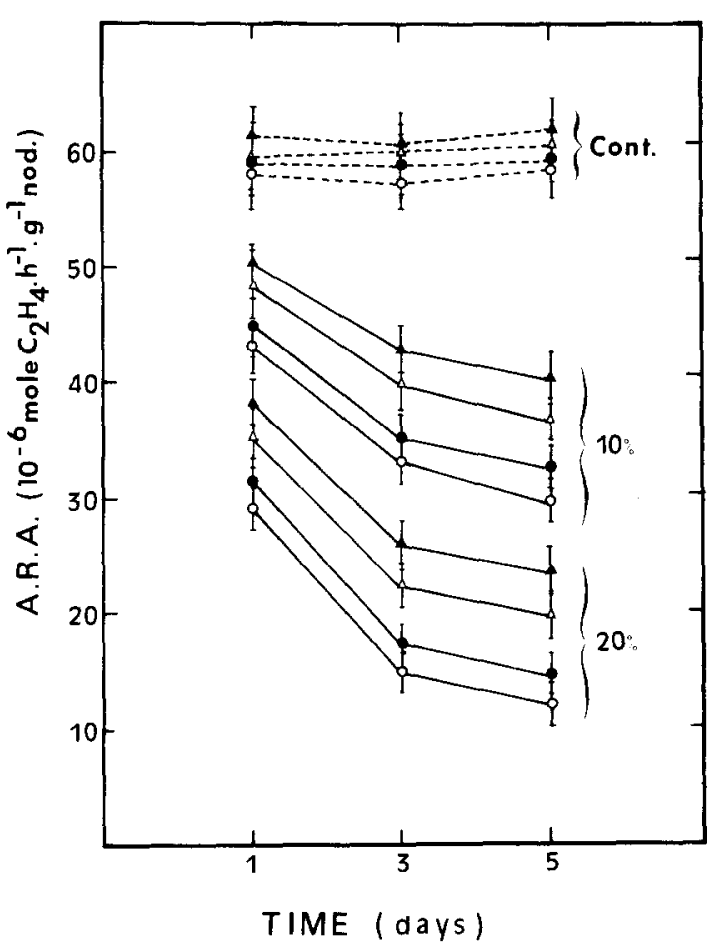

Fig. 3. Nitrogen fixation $\mathrm{N}_{2}$ (Acetylene reduction activity) of the 2 varieties during the osmotic stress induced by PEG $(0,10$ and $20 \%$ ) under 2 levels of $\mathrm{K}: \mathrm{K}_{1}=0.005$ and $\mathrm{K}_{2}=5 \mathrm{mM}$. $\wedge$ Crau $\mathrm{K}_{2}, \Delta$ Crau $\mathrm{K}_{1}$; $\bullet$ Huia $\mathrm{K}_{2}$; O Huia $\mathrm{K}_{1}$.

\section{Acetylene Reduction Activity}

The nitrogen fixation capacity was estimated by ARA measurements (Fig. 3). The non-stressed plants showed no significant differences between varieties and treatments. For the PEG-treated plants the ARA declined rapidly towards the end of the experiment. The decline was less pronounced after 3 days. The inhibition of the nitrogenase activity was more severe with $20 \%$ PEG.

Significant differences were observed between the varieties, Crau exhibiting the highest ARA values. Furthermore the $\mathrm{K}_{2}$ treatment increased ARA more than the $\mathrm{K}_{1}$ treatment.

A significant "cultivar-PEG" interaction was also observed, showing a differential effect of PEG on the varieties. Significant correlations also existed between ARA and water potential $(0.86<\mathrm{r}<0.92)$ and between ARA and stomatal conductance $(-0.85<\mathrm{r}<-0.89)$. 
Table 1. Nodule mass $\left(\mathrm{g} \cdot\right.$ plant $\left.^{-1}\right)$, nodule number (per plant) and nodule water content $(90 \%$ of the controls)

\begin{tabular}{|c|c|c|c|c|c|c|c|c|c|c|}
\hline \multirow[t]{3}{*}{ Variety } & \multirow{3}{*}{$\begin{array}{l}\mathrm{K} \\
\text { level }\end{array}$} & \multicolumn{3}{|l|}{ Control } & \multicolumn{3}{|c|}{$10 \%$ PEG } & \multicolumn{3}{|c|}{$20 \%$ PEG } \\
\hline & & \multicolumn{2}{|l|}{ Nodule } & \multirow{2}{*}{$\begin{array}{l}\text { Water } \\
\text { content } \\
(\%)\end{array}$} & \multicolumn{2}{|l|}{ Nodule } & \multirow{2}{*}{$\begin{array}{l}\text { Water } \\
\text { content }\end{array}$} & \multicolumn{2}{|l|}{ Nodule } & \multirow{2}{*}{$\begin{array}{l}\text { Water } \\
\text { content }\end{array}$} \\
\hline & & number & $\begin{array}{l}\text { f. wt } \\
(\mathrm{mg})\end{array}$ & & number & $\begin{array}{l}\text { f. wt } \\
\text { (mg) }\end{array}$ & & number & $\begin{array}{l}\text { f. wt } \\
(\mathrm{mg})\end{array}$ & \\
\hline \multicolumn{11}{|l|}{ Ist day } \\
\hline \multirow[t]{2}{*}{ CRAU } & $\mathrm{Kl}$ & 33 & 22 & 100 & 32 & 19 & 90 & 33 & 17 & 84 \\
\hline & $\mathrm{K} 2$ & 45 & 25 & 100 & 41 & 18 & 90 & 42 & 17 & 86 \\
\hline \multirow[t]{2}{*}{ HUIA } & $\mathrm{K} 1$ & 30 & 17 & 100 & 27 & 8 & 79 & 29 & 12 & 74 \\
\hline & $\mathrm{K} 2$ & 43 & 19 & 100 & 38 & 15 & 80 & 37 & 14 & 75 \\
\hline \multicolumn{11}{|l|}{$3 r d$ day } \\
\hline \multirow[t]{2}{*}{ CRAU } & $\mathrm{K} 1$ & 39 & 18 & 100 & 35 & 17 & 82 & 35 & 23 & 76 \\
\hline & $\mathrm{K} 2$ & 51 & 21 & 100 & 45 & 29 & 84 & 45 & 32 & 78 \\
\hline \multirow[t]{2}{*}{ HUIA } & $\mathrm{K} 1$ & 32 & 17 & 100 & 30 & 10 & 68 & 29 & 16 & 61 \\
\hline & $\mathrm{K} 2$ & 43 & 18 & 100 & 40 & 14 & 69 & 39 & 25 & 63 \\
\hline \multicolumn{11}{|l|}{ 5th day } \\
\hline \multirow[t]{2}{*}{ CRAU } & K1 & 33 & 20 & 100 & 40 & 28 & 79 & 37 & 28 & 73 \\
\hline & $\mathrm{K} 2$ & 52 & 35 & 100 & 49 & 39 & 80 & 45 & 30 & 71 \\
\hline \multirow[t]{2}{*}{ HUIA } & $\mathrm{K} 1$ & 34 & 16 & 100 & 33 & 15 & 65 & 33 & 20 & 58 \\
\hline & $\mathrm{K} 2$ & 45 & 22 & 100 & 41 & 22 & 68 & 40 & 29 & 60 \\
\hline
\end{tabular}

\section{Modifications of the N-fixing system}

Table 1 shows the nodule number per plant, mass and water content of the nodules during the five days of treatment. Crau showed the highest values for each parameter and this variety also had better leaf and root development. The mass of the nodules (FW) was decreased by the osmoticum, but increased by the high $\mathrm{K}$ concentration. The number of nodules increased with time and was systematically higher in the controls than in the treated plants. "Variety" and " $\mathrm{K}$ " were significant treatment effects. The water content of the nodules decreased with the osmoticum concentration. This effect was lower in the presence of $\mathrm{K}$.

\section{Discussion and conclusions}

Potassium is a major element influencing the leaf-water status (Mengel, 1984) and osmotic processes in plants. The movement of stomatal guard cells is dependent on the potassium movements in these cells (Humble and Raschke, 1971). The leaf-water status can be described by the leafwater potential and the stomatal resistance. Previous research has clearly demonstrated that severe plant-water deficits are associated with in- creasing stomatal resistance (Bennett et al., 1987; O'Toole et al., 1977), at low leaf-water potentials. In alfalfa, a severe $\mathrm{K}$ deficiency generally brings on an increase in the stomatal closure (People and Koch, 1979). A low potassium concentration in the nutrient solution produced plants with a high transpiration rate (Brag, 1972). In our work we have used a hydroponic system to study the response of white clover to a stress induced by an osmotic agent.

The results show clearly that potassium is an essential factor determining the resistance to water stress and the water balance of white clover. The water potential decreases in relation to the potassium content of the culture medium.

The stomatal resistance is a sensitive indicator of plant-water stress (Finn and Brun, 1980). This parameter has long been recognized as a key factor influencing the leaf gas exchanges by regulating the diffusion of water vapor and $\mathrm{CO}_{2}$ (Stiles, 1970). Further, carbohydrate availability is limited when the leaf-water potential and the photosynthetic activity decrease (Engin and Sprent, 1973). In addition, a decreasing $\mathrm{K}^{+}$supply generally reduces the assimilate translocation (Mengel and Kirkby, 1982). Water stress may induce indirectly an inhibition of the nitrogenase activity of plants, by reducing the photosynthetic activity (Huang et al., 
1975a; 1975b). In this work we have observed that the osmotic stress resulted in a rapid decrease in nitrogen fixation. Moreover, a potassium deficiency increased the severity of the nitrogenase inhibition. This inhibitory effect can be explained by direct processes. Water stress might modify the membrane permeability of the nodules, thereby inducing a direct effect on nodule morphology and physiology (Engin and Sprent, 1973). In this work, the osmotic stress of white clover directly affected the number, water content and weight of nodules. Water stress can increase the resistance to oxygen transport (Pankhurst and Sprent, 1975), with severe water deficit damaging membrane-bound oxidases (Sprent, 1976).

Differences in water-stress resistance have been observed between white clover varieties (Shamsunnoor et al., 1989). Our work confirmed these results: Crau (Ladino) was more tolerant of the deficit than Huia (Hollandicum).

The Crau variety showed better nitrogen fixation under stress. This resistance to water stress was reinforced by a high supply of potassium. Potassium uptake by plants decreases under water stress conditions and consequently reduces the root absorbing power (Hsiao, 1973). Here Crau maintained $\mathrm{N}$-fixation, therefore its ability to resist a water stress was probably due to a better water use and nutrient uptake efficiency. In conclusion, under these controlled conditions, potassium plays an important role in the tolerance to the water deficit of the white clover, and the tolerance depends partly on the variety.

\section{Acknowledgements}

We thank Dr J L Morel for his assistance in the English translation and the anonymous reviewers for valuable manuscript suggestions.

\section{References}

Balandreau $\mathbf{J}$ and Dommergues Y 1973 Assaying nitrogenase $\left(\mathrm{C}_{2} \mathrm{H}_{2}\right)$ activity in the field. Bull. Res. Comm. (Stockholm) 17 , 247-254.

Bennett J M, Sinclair T R, Muchow R C and Costello S R 1987 Dependence of stomatal conductance on leaf water potential, turgor potential, and relative water content in field-grown soybean and maize. Crop Sci. 27, 984-990.
Brag H 1972 The influence of potassium on the transpiration rate and stomatal opening in Triticum aestivum and Pisum sativum. Physiol. Plant. 26, 250-257.

Engin M and Sprent J I 1973 Effects of water stress on growth and nitrogen fixing activity of Trifolium repens. New Phytol. $72,117-126$.

Finn G A and Brun W A 1980 Water stress effects on $\mathrm{CO}_{2}$ assimilation, photosynthate partitioning, stomatal resistance, and nodule activity in soybean. Crop Sci. 20, 431-434.

Guckert A and Laperriere C 1987 Effet du stress hydrique sur la fixation d'azote par le trèfle blanc (Trifolium repens $L$.). Coll. Nutrit. Azot. Legum. Versailles 19-21 nov. 1986. Les Coll. de I'INRA 37, 245-250.

Hsiao T C 1973 Plant responses to water stress. Annu. Rev. Plant Physiol. 24, 519-570.

Huang C Y, Boyer J S and Vanderhoef L N 1975a Acetylene reduction (nitrogen fixation) and metabolic activities of soybean having various leaf and nodule water potentials. Plant Physiol. 56, 222-227.

Huang C Y, Boyer J S and Vanderhoef L N 1975b Limitation of acetylene reduction (nitrogen fixation) by photosynthesis in soybeans having low water potentials. Plant Physiol. 56, 228-232.

Humble G D and Raschke K 1971 Stomatal opening quantitatively related to potassium transport. Plant Physiol. 48, 447-453.

Mengel K 1984 Le potassium en physiologie végétale, C.R. Acad. Agric. Fr. 70, 1365-1376.

Mengel K and Arneke W W 1982 Effect of potassium on the water potential, the pressure potential, the osmotic potential and cell elongation in leaves of Phaseolus vulgaris. Physiol. Plant. 54, 402-408.

Mengel K and Kirkby E A 1982 Principles of plant nutrition. Intern. Potash Inst., Bern, Switzerland.

O'Toole J C, Ozbun J L and Wallace D H 1977 Photosynthetic response to water stress in Phaseolus vulgaris. Physiol. Plant. 40, 111-114.

Pankhurst C E and Sprent J I 1975 Effect of water stress on the respiratory and nitrogen fixing activity of soybean root nodules. J. Exp. Bot. 36, 287-304.

People T R and Koch D W 1979 Role of potassium in carbondioxide assimilation in Medicago sativa L. Plant Physiol. 63, 878-881.

Schölander P F, Hammel H T Bradstreet E D and Hemmingsen E A 1965 Sap pressure in vascular plants. Science 148, 339-346.

Shamsun-noor L, Robin C, Schontz D, Heulin T and Guckert A 1988 Effet d'un déficit bydrique sur le trèfle blanc (Trifolium repens $L$.). I. Importance du cultivar. Agronomie (In press).

Sprent J I 1972 The effects of water stress on nitrogen-fixing root nodules. IV. Effects on whole plants of Vicia faba and Glycine max., New Phytol. 71, 603-611.

Sprent J I 1976 Nitrogen fixation by legumes subjected to light and water stresses. In Symbiotic nitrogen fixation in plants. Cambridge Univ. Press. Ed. P S Nutman. pp 405-420.

Stiles W 1970 A diffusive resistance porometer for field use. I. Construction J. Appl. Ecol. 7, 617-638.

Sundström K R and Huss-Danell K 1987 Effects of water stress on nitrogenase activity in Alnus incana. Physiol. Plant. 70 , $342-348$. 
Turner N C 1986 Crop water deficits: A decade of progress. Adv. Agron. 39, 1-51.

Van Bavel C H M, Nakayama F S and Ehrler W R 1965 Measuring transpiration resistance of leaves. Plant Physiol.
$40,535-540$.

Wood M, Cooper J E and Holding A J 1983 Method to assay the effects of soil acidity factors on legume Rhizobium symbioses. Soil Biol. Bioch. 15, 123-124. 